\title{
Religious Moderation in Indonesian Mosques: A Study of Two Mosques in the Bekasi City
}

\author{
Anik Farida $^{1}$, Mary Silvita ${ }^{2}$ \\ \{anikfarida16@gmail.com¹, mary.silvita@uinjkt.ac.id²\} \\ Center for Research and Development for Religious Life, Ministry of Religious Affairs, \\ Indonesia ${ }^{1,}$ \\ Center for Indonesian Cultural Initiatives ${ }^{2}$
}

\begin{abstract}
This paper discusses the conception of religious moderation by mosque organizers (a.k.a. DKM or Takmir Masjids), covering perspectives, attitudes and practices of religious moderation. The mosques under study are the Great Mosque of al-Barkah and the Nurul Islam Mosque in Bekasi City, West Java, Indonesia. Al-Barkah is a mosque representing the state because its management and funding comes from the state budget. The mosque's operational activities are under the control of the Bekasi City government. Meanwhile, Nurul Islam is a mosque managed by the community, under the KH Noer Alie Islamic Center Foundation, whose management and funding are independently under the foundation's control. The research was conducted during the Covid-19 pandemic in 2020, considered as a context to test the resilience of the mosque in maintaining the values of religious moderation in difficult situations. This study finds that the concept of religious moderation in the two mosques is different with the determinant variable is the subject, in which Al-Barkah as a mosque representing the state translates religious moderation in so far as all educational programs held are in line with government programs. The assumption is that the government is certain to have moderate perspectives, attitudes and practices in religion. Thus, differences in conceptions from the government are considered non-moderate. Meanwhile, the Nurul Islam Mosque, translating the concept of religious moderation in the middle path; it does not side with the views of the extreme right or the extreme left. However, this study also suggests that both mosques have something in common, namely, that religious moderation in these mosques has only reached the level of moderate perspectives and attitudes, not so much in the religious practices. In terms of tolerance, the views shown are strongly influenced by the narrative of majority and minority.
\end{abstract}

Keywords: Pandemic, Religious Moderation, Mosque, Bekasi City

\section{Background}

In a religious context, extreme views, attitudes, and behaviors often encourage adherents to refuse to accept other people's views of truth, and instead these factors persist in their own interpretation of the truth. It is from here that the term "hardline", or extremism, is associated with religious practice. To understand the landscape of extremism, or hardline religion, both conceptually and empirically, we need to understand the significance of strengthening the vision of religious moderation. Extreme religious attitudes are obviously a major challenge for religious communities. In 2020, when the pandemic has been going on for 
half the year, the attitude of extreme diversity is also a big issue that cannot be ignored. This issue has appeared several times during the pandemic.

On the other hand, mosque is perhaps one of the best places to strengthen religious moderation. This is in line with the spirit and soul of the mosque as the center of civilization and cultural identity for Muslims. Etymologically, mosque is taken from the root word "sujud" which means obedient, submissive with respect to God's will. Then, in Islam, the essence of the mosque is a place for all activities (not just prayers) as a manifestation of obedience to God. So "sujud" or prostration in the physical sense means movement, and prostration in the inner sense is devotion. Therefore, devotion will indeed have a wider meaning than just a place of prostration.

As a center of civilization, mosque is very strategic. It is a place for inclusive and moderate religious attitudes. For this reason, it is necessary to develop a model of a mosque as a center for religious moderation. Based on these considerations, our research questions are:

- What perspectives, attitudes and practices of moderation education are carried out by the mosques?

- What strategies are in place in the mosques to develop religious moderation?

- What are the supporting and inhibiting factors in religious moderation in mosques?

\section{Locus: Two Different Prototypes of the Mosque}

The focus of this research study is two largest mosques in Bekasi City, namely the Great Mosque of al-Barkah and the Nurul Islam Mosque at the KH Noer Alie Islamic Center Foundation, Bekasi City. The Great Mosque of al-Barkah was chosen because it is a mosque representing the state. This mosque is managed by the Mosque Management Body, chaired by the Regional Secretary of Bekasi City, namely Dr. Reny Hendrawati. The task of the Management Body who was inaugurated by the Mayor of Bekasi City Dr. Rahmat Efendi in December 2019, is to provide Mosque's careful planning and good management, and a strong commitment for the success of carrying out the vision and mission of the Mosque.

The Mosque's management body must report all administrative activities both orally and in writing to the Mayor. In addition, the task of the management body is also to prepare a financing plan, including the maintenance and welfare of mosque management officers. Thus, the operational financing of the Al-Barkah Mosque is borne by the Bekasi City government. This is the reason why we called that the Great Mosque of Al-Barkah is a representation of the state mosque.

At first glance, a moderate impression appears from the mosque architecture. There are large minarets on the four corners of the Great Mosque of Al-Barkah. Two larger towers at the front and two smaller towers at the rear of the Mosque. The roof of the mosque is decorated with one main dome in blue with transverse accents and four small domes. The main door made of teak wood with geometric carvings, a typical of the Middle East architecture, will immediately welcome visitors.

When we enter the room in the mosque, we saw Jepara carved ornaments, especially on the pulpit and mihrab. This gives the impression that architecturally this mosque is very adaptive to local culture, namely Javanese culture. The acculturation process occurs by combining typical Middle Eastern geometric carvings on the dome and door with the Jepara architecture in the space in the mosque, namely the mimbar and mihrab. In this way, this mosque truly signifies a beautiful and dialogic blend of Middle Eastern and Javanese culture.

In contrast to the Great Mosque of al-Barkah, Nurul Islam Mosque, KH Noer Alie Islamic Center Foundation is an independent mosque that is not affiliated with the government, nor is it supported by government funding. All mosque activities are fully funded 
by the KH Noer Alie Islamic Center Foundation as well as the implementation of its activities, are all coordinated and reported to the KH Noer Alie Islamic Center Foundation. The idea of establishing an Islamic Center in Bekasi came from KH. Noer Alie, an Indonesian National Hero, when on one occasion he told the Regent of Bekasi H. Suko Martono as follows: "Saudara Bupati, we don't have yet here anything like an Islamic Center. While you are a Regent, think about how to make it happen."1

The Bekasi Islamic Center is also equipped with a mosque building, namely the Nurul Islam Mosque as a donation from the Amal Bhakti Muslim Pancasila Foundation. This mosque construction began in mid-1992. Its construction was completed in July 1993. Meanwhile, the inauguration inscription was signed by President Soeharto.

According to information from a number of initial informants, Nurul Islam Mosque is considered as one of the mosques that can represent Islamic moderation, because based on the informants' experience, this mosque is quite open as it often hold programs and studies with diverse speaker backgrounds, from moderate to extreme ones. Although this mosque is not funded by the government, this mosque is considered to be quite disciplined in following government regulations in carrying out its activities. In the meantime, the al-Barkah mosque, because it is a local government mosque whose overall activities are within the corridors implemented by the government, this mosque should have implemented the moderation education function which is the government's national agenda, both at the central and regional levels.

\section{Perspectives, Attitudes and Practices of Religious Moderation in Mosques}

Tolerance is one of the important teachings in Islam, and attitudes and practices of religious moderation place great importance on being open and tolerant of differences. Unfortunately, in many places this tolerance is still limited only in views and attitudes, it has not yet become part of daily practice. ${ }^{2}$

Moderation in thinking is characterized by the ability to combine between context and the existing text. This means that religious thinking is not solely based on textual arguments, so that reality and context are forced to submit to the text. This way of thinking will encourage religious communities to move away from the ideals and main intentions of the religious messages themselves. This is because the text is not read in its context.

In the context of Bekasi City, in so far as the mosques under study, the religious activities are moderate. The local government acknowledges that it often carries out supervision, especially for mosques that are affiliated with the government. However, the supervision cannot be fully carried out, what is often done is coordination and appeals. As happened in the controversy regarding the pandemic outbreak and the Bekasi City government circular so that activities in places of worship such as mosques follow health procedures, there are still a few problems, as explained by a local government official below:

"So far, related to the pandemic, we have distributed circular letters to mosques regarding congregational worship. Incidentally, on Friday two weeks ago we said that we had made a regulation between the distance of the congregation, it had to be physical distancing, but the preacher protested: why are the jama'ah given a distance? this is a provocation to the

\footnotetext{
${ }^{1}$ Interview with KH. Abid, as chairman of the Islamic Center Foundation, who is also the grandson of KH. Noer Alie, on July 6, 2020.

${ }^{2}$ Jeremy Menchik, Islam and Democracy in Indonesia: Tolerance without Liberalism (Cambridge:

Cambridge University Press, 2015).
} 
congregation. Because of that we made a warning letter to the DKM so that the khotib concerned would not be used again in the future, because it had provoked the congregation."

It is imperative to note that many mosques in big cities are managed independently. Occasionally they coordinate with local governments, but more often than not they plan, organize and promote their religious activities openly and independently. As a result, the government cannot always supervise to what extent and how fat the implementation of religious activities are carried out in these houses of worship.

Moreover, in Bekasi City there is only one mosque which is officially and financially funded by the Bekasi City budget, namely the Grand Mosque of al-Barkah. This number is considered to be less compared with other cities, which generally have three or more government-funded mosques. Even so, the government still controls activities in mosques, although not regularly.

During the Pilkada and Presidential Election since 2014, it is no secret that mosques are often used as campaign arenas. When the Pilkada, Pilgub and Pilpres were over, political issues never really moved away from the mosque. People love to discuss and discuss political matters in open spaces, and mosque administrators often invite preachers and preachers who openly and openly criticize the government. Or they transparently provide critical attitudes and views towards those who are considered detrimental to Muslims.

It seems that the Bekasi City government is not unaware of this. However, it seems that they are being very careful, and don't want to make the problem appear bigger. There is a sense of freedom of the pulpit, in the sense that there are many speakers in the mosque who speak freely and openly. The government has limited supervision. As explained by one Bekasi City government official below:

"There is a government mosque, Masjid al-Barkah. Just to supervise, if the preacher upsets the atmosphere or disturbs the public, we will no longer invite the Ustadz... If he is critical of the government, we are actually grateful, but if he has cornered government policies, that is what we will protect." 3

So, the freedom of the existing pulpit still allows preachers to talk about religion and socio-political issues. However, it seems that there is no clear and firm corridor regarding the intolerant and discriminatory attitudes of the speakers. It is only limited to an appeal and no longer invites speakers who are considered problematic.

However, based on the results of our interviews with a number of parties at the Grand Mosque of al-Barkah — a mosque funded by the Bekasi City government, religious moderation here is not necessarily better than other mosques that are not intervened by the government. The nursery for the values of religious moderation actually appears more dynamic and livelier in non-government mosques. This proves that government control is not really the determinant that the quality of religious moderation in mosques will be better.

The DKM or the management of the al-Barkah mosque also practically still uses a priori expressions and negative labels on people or activities carried out by certain groups of Muslims towards other religious communities. As an excerpt from our interview with one of the administrators and imams of the al-Barkah Mosque:

"In Bekasi there are also many secular NU (Nahdlatul Ulama) personalities who are also active in the Church. This is truly inviting to qiyamat (apocalypse). Yes, earlier, they meet

${ }^{3}$ Interview with H. Mardanih., SE., M.Si (Head of Bekasi City Social Welfare) \& Ridan, S.Ag (Head of Sub Division of Religious Development) on July 6, 2020. 
with the Mayor, they are very happy. It makes no difference how muamalah, how worship. This language is not exactly right, but make them murtad (apostate) already. Am I, right? They are participating in kebaktian (Christian religious gathering) programs, for reasons of tolerance. "4

"We, alhamdulillah, are all Muslims (laughing). Even our chairman is currently a Police man, who has no background in religious organizations. There are also some who are business entrepreneurs. Even if it is NU, we are here, moderate NU. Because there are three types of NUs; Traditional, Moderate and Secular. So, we are moderate NU. " 5

"For people who read yasinan only, it's traditional NU. But if NU is moderate, it doesn't just read Yasin. Now for the secular NU, they don't do the Qur'anic gathering (laughing)."6

The level of loyalty and obedience of the Mosque to the recommendations of the Bekasi City government also greatly depends on how and what form of relationship that is built by the government with the Mosque management. For example, whether the government consistent enough to pay attention to the prosperity of the Mosque or not, whether the government officials are active enough to attend congregational worship at the Mosque or not, or whether the government always keeps its promises to them or not.

Things like these also affect the level of trust and respect of Mosque administrators to the government concerned. This trust and respect then affect the level of compliance of the Mosque administrators with the instructions given to them by the government.

Unlike the Great Mosque of al-Barkah, the Nurul Islam Mosque which is under the control of the KH Noer Alie Foundation's Islamic Center does not appear to have an instructional relationship with the Bekasi City government. This is quite reasonable, because all mosque activities here are independently funded by the Foundation and the community. Nevertheless, Nurul Islam Mosque at the KH Noer Alie Foundation's Islamic Center has always shown a commitment to maintaining a harmonious relationship with the government. Such a thing is a supreme mandate that has been passed down from their predecessors.

The KH Noer Alie Islamic Center Foundation, which houses the Nurul Islam Mosque, is a foundation whose administrators are recruited based on kinship or trah relationships from KH Noer Alie's extended family. As the founder of the Islamic Center Foundation, KH Noer Alie has provided an example of how Muslim communities should work together with the government, with fellow Muslims and with other religious communities, in order to create an Islamic community order that is both safe, secure and peaceful.

As a direct descendant of KH Noer Alie, Mr. Abid Marzuki, the head of the KH Noer Alie Islamic Center Foundation said that KH Noer Alie is an example of ulama (scholars) who have a great love for his country, his homeland. He is also an example of a very moderate scholar. In its history, the KH Noer Alie Islamic Center (formerly known as the Bekasi Islamic Center) is the forerunner to the establishment of the first Ulama Council in Indonesia, namely the West Java Ulama Council. KH Noer Alie's national commitment was clearly visible when he appointed H.R. Soedarsono, Commander of the Siliwangi Military Region (Pangdam), as chairman of the West Java Ulama Council. From here, the idea of forming the

\footnotetext{
${ }^{4}$ Interview with DKM Al-Barkah (Ustadz Nur Rohim, Ismail and Irfan) on July 7, 2020.

${ }^{5}$ Interview with DKM Al-Barkah (Ustadz Nur Rohim, Ismail and Irfan) on July 7, 2020.

${ }^{6}$ Interview with DKM Al-Barkah (Ustadz Nur Rohim, Ismail and Irfan) on July 7, 2020.
} 
Indonesian Ulema Council was born. When MUI was born, KH Noer Alie's commitment to unity was also seen when he chose Buya Hamka, who incidentally had a Muhammadiyah background as the first chairman of the MUI.

What was done by KH Noer Alie, who has been recorded as history, was followed by the next generation. Mr. Abid said, KH Noer Alie had laid the foundation of the spirit of "ukhuwah Islamiyah" without differentiating between Islamic schools and groupings in synergy for the greater interest, namely the interests of the "ummah" as a whole, the interests of the nation and the Indonesian state.

Nurul Islam Mosque also prioritizes the spirit of protecting all groups and schools of thought (mazhab), but is still in the corridor that fulfills the principle of "Wihdah," namely the mazhab or sect must uphold the Akidah and Tauhid, and understand "Ahlu Sunnah wal Jama'ah." So, all groups are accepted, except for those that had been declared deviant by the Ulama Council. ${ }^{7}$

Therefore, it is not surprising that, in plain view, we can see the plurality of schools of thought in the Nurul Islam Mosque. Starting from Salafis, Wahabi, NU, Muhammadiyah and so on. Groups such as Shi'ah, Ahmadiah or LDII are also welcome if they want to worship at the Nurul Islam Mosque, but not to hold study activities aimed at spreading their understanding. That is because the Council of Ulama has stated that their understanding has deviated from the Islamic teachings of "Ahlu Sunnah wal Jama'ah." The aim is to protect people from deviant creed.

The national commitment of KH Noer Alie as the initiator of the Islamic Center is also seen in his rejection of the formation of the United Republic of Indonesia (RIS). At that time KH Noer Ali announced a resolution which read: 1. Removing Bekasi from Jakarta, 2. Including Bekasi to West Java province (to become a thorn in the flesh), and 3. Returning Indonesia to become a Unitary State (NKRI). This national commitment was later also proven by the crowning of KH Noer Ali as "the national hero of the Republic of Indonesia" for three reasons; the Rawa Gede incident, the Bekasi people's Apel Raya, and the formation of the Indonesian Ulema Council.

Furthermore, Mr. Abid strengthened the proof of KH Noer Ali's national commitment when he disagreed with the government. As a former warlord with a religious background, $\mathrm{KH}$ Noer Ali is one of the opponents of a single principle, not against Pancasila, but rather a single principle obligation which is considered to be shackling all existing mass organizations.

However, his critical attitude towards the government did not necessarily lead him to use the ummat to oppose the government. KH Noer Ali actually prohibits his congregation from being different from the government in matters of publicity and worship. Mr. Abid said:

"Political ijtihad may be different, but don't let the differences be drawn to the area of worship. For public affairs issues, we must follow the jumhur of ulama and the government." 8

Even though the Nurul Islam Mosque has shown a very strong national commitment and maintains a harmonious relationship with the government, the Nurul Islam Mosque of the KH Noer Alie Islamic Center Foundation is not against those groups who have been critical of the government. So, it never refuses a lecturer or ustadz who is prohibited from speaking again if in his lecture the person concerned strongly criticizes the government,

\footnotetext{
${ }^{7}$ Interview with Drs. Ahmad Saad Hamdany and Dr. H. M. Abid Marzuki Lc. M.Ed on July 6, 2020.

${ }^{8}$ Interview with Drs. Ahmad Saad Hamdany and Dr. H. M. Abid Marzuki Lc. M.Ed on July 6, 2020.
} 
as long as the criticism is conveyed in a justified manner, which does not contain slander and hoaxes.

Under normal conditions, activities at the al-Barkah Mosque can be seen in the form of the Majlis Taklim (Ta'lim Council), Saturday Sunday studies, youth associations, short lectures after compulsory prayer, sermons, recitation of the Qur'an, tahfiz qur'an, studies of Muslim shohih hadiths, study of book of Sufism, Ihya Ulumuddin, and the implementation of commemoration of religious holidays. This Mosque is also open to activities proposed by external parties or the general public who wish to use the mosque properly. All parties who wish to conduct a study at the mosque must coordinate in advance with the DKM management by attaching their proof of identity, title and theme of the study gathering to be held and the speaker, who will give lectures during the study gathering.

Any implementation of religious gatherings conducted by external parties will be directly selected by the Mosque leadership. Even though they do not apply too strict rules, the DKM will always remind all parties who will conduct a study gathering at this Mosque "not to discuss khilafiyah matters," let alone convey material that has the potential to offend other groups or that are provocative in nature. As said by one of the Imams of the al-Barkah Mosque below:

"For parties who wish to become presenters in our study, they will be selected first, directly by Kiyai Jamaksari. He is more qualified in knowledge, because he has become a National and International Council of Judges, he has many communications and connections." 9

"We will see what material to convey about, and who is delivering it. From the beginning, we always said that we should always take care of the material, please don't touch the issues of khilafiyah. Rather, prioritizing and maintaining the spirit of "ukhuwah Islamiyah," the brotherhood of all Muslims, and avoiding materials that would make friendship between Muslims difficult to materialize."10

"Marbots (Mosque organizers) are also used to controlling this kind things, if there is a speaker or lecturer that slanders others, then in the future we will not give them another chance. But if it doesn't get off track, that's okay. We don't have to make this mosque, exclusively all $N U$. "11

However, during the pandemic, practically all communal activities in mosques were eliminated, and only reopened during the "new normal" period. At this time the mosque returned to carrying out congregational prayers and routine studies but by implementing the Covid-19 health protocol, namely by providing disinfectant booths, establishing safe disinfectant for prayer shafts, eliminating general prayer equipment such as prayer mats, sarongs and mukena, and obliging all worshipers' to immediately leave the mosque when the worship and study activities were over. It is forbidden to sit and chat with fellow congregation as is usually done in normal situations.

\section{Indicators of Religious Moderation}

Both the al-Barkah mosque and the Nurul Islam mosque of the KH Noer Alie Islamic Center Foundation have their own ways of controlling the quality of religious moderation in

9 Interview with DKM Al-Barkah (Ustadz Nur Rohim, Ismail and Irfan) on July 7, 2020.

${ }^{10}$ Interview with DKM Al-Barkah (Ustadz Nur Rohim, Ismail and Irfan) on July 7, 2020.

${ }^{11}$ Interview with DKM Al-Barkah (Ustadz Nur Rohim, Ismail and Irfan) on July 7, 2020. 
their respective places. The Nurul Islam Mosque, for example, maintains the neutrality of religious material delivered at the mosque, the DKM has a stamped agreement document that must be signed by all parties who will use the mosque to carry out study activities according to the vision of the Nurul Islam mosque, as explained in the document below:

"In accordance with the vision and mission of the Bekasi Islamic Center, which always prioritizes UKHUWAH, WIHDAH and SYIAR in carrying out Islamic study activities at the Islamic Center, I will comply with the regulations not to provide study material that is" khilafiyah Furu'iyyah "which can break the diversity" manhaj, ukhuwah. Islamiyah "and the Ummah Union. If that happens, then we are willing to be evaluated so that we will not be a user of the Nurul Islam Islamic Center Bekasi Mosque in Islamic studies conducted at the Bekasi Islamic Center. "12

In the course of their journey, they do not always comply with what is agreed upon, such as the rule of "not discussing furu'iyah matters." If this happens the DKM will take a policy, that is, if it happens in an internal review, the cleric will be eliminated or dropped from the Ustadz (speaker) list.

If it happens in an external study, the microphone or loudspeaker will be turned off directly by the Marbot, who is always on location standby for every event, and the speaker will not be allowed to speak in the study at a later date. As stated by Mr. Saad the secretary of the DKM Nurul Islam as follows:

"We have eliminated ustadz who fill the study several times, maybe four times. The limits that cannot be tolerated here are indeed that, one cannot blame them, and disbelieve because they are different."13

"In the past, before I was here (before 2019), there were 40 Majelis Ta'lim held here, now they have been trimmed down so that now there are 12 Majelis Ta'lim only. Before I became a committee member, there used to be even "war training" here. But now it's banned. This is the process of screening this study as well as the consideration is that we must return to the khittah and vision and mission of the founding of this foundation by KH Noer Alie that everything we do here must be oriented to three basic principles, namely "Syi'ar, Ukhuwah and Wihdah." If it's just a study, we might only get the syi'ar, but it can destroy the wihdah if the content of the study contains coercion, wrongly blames and declare kafirs to others of different opinions. This is not justified."14

In terms of religious moderation, the mosque's DKM is quite open and independent from outside influences, even the influence of the government is relatively small. However, many members of the DKM mosque administrators are affiliated with religious organizations such as NU, so the religious attitudes and views of these organizations also influence the mosque

However, what is happening now is actually a transformation due to the new DKM management since 2019. Previously, until 2018, the Nurul Islam Mosque had become a center for religious activities for groups that tended to be intolerant and radical, as reported by couple of studies and newspapers at the time.

12 Print out of MoU paper for external user of Nurul Islam Mosque

${ }^{13}$ Interview with Drs. Ahmad Saad Hamdany and Dr. H. M. Abid Marzuki Lc. M.Ed on July 6, 2020.

${ }^{14}$ Interview with Drs. Ahmad Saad Hamdany and Dr. H. M. Abid Marzuki Lc. M.Ed on July 6, 2020. 
The Nurul Islam Mosque prioritizes the spirit of protecting all groups and mazhabs, but is still in the corridor that fulfills the principles of Wihdah, namely the mazhab or sect must uphold the creed and Tawhid, and understand "Ahlu Sunnah wal Jama'ah." So all groups can be accepted, except for those that have been clearly declared "deviant" by the Ulama Council. Fatwas from MUI as the Ulama Council in Indonesia are considered as the most authoritative jurisprudence for Indonesian Muslim. Therefore, most of mosques in Indonesia, either it is government affiliated or the non government affiliated one, are most likely to follow the fatwas.

Unlike the Nurul Islam Mosque, the al-Barkah Mosque does not have standard rules and certain blueprint documents as a guide for carrying out activities at this mosque. Quality Control of religious moderation at the al-Barkah mosque is carried out by a selection process of studies to be held at the mosque, and supervision during the process of the gatherings. Parties and groups that deviate from the message that has been conveyed not to convey divisive (memecah-belah) messages and materials will be reminded by a process of "familial" dialogue (kekeluargaan). Parties deemed to be uncooperative will be prohibited from holding any more activities at the al-Barkah mosque in the future.

\section{Supporting Factors}

In our view, based on our interviews and observation during this study, the supporting factors for strengthening religious moderation in mosques are as follows. First, there is involvement or self-involvement between mosque administrators and activists with civil society institutions that are known for their moderate attitudes and views, like large religious organizations such as NU and Muhammadiyah.

This engagement factor is important to note considering the role and influence of groups, mass organizations or institutions known for their non-open, intolerant or discriminatory attitudes and views which also usually help to influence the attitudes and views of the management, activists and mosque congregations in the area. This can occur as a result of planning, implementing activities and mobilizing the resources involved in mosque activities which are closely related to the activity model, the content of the material and who is invited to fill in the material cannot be separated from how close or how far they are from influencing institutions to the mosque.

Indeed, a close association with these mass organizations is not a guarantee. However, involvement or self-involvement in the context of engagement at least provides an opportunity for planning, implementation and mobilization of resources that are closer to their attitudes and views, than others.

Second, there are charismatic figures who have a major role and influence for mosque administrators, activists and congregations. DKM mosque managers who have a respectful attitude and inherit certain values from the charismatic figure can encourage the creation of planning, implementation and mobilization of resources that better reflect the values held or taught by the charismatic figure. Sociologically, the internalization of these values can develop and grow in an environment or milieu which also supports the creation of a harmonious and conducive atmosphere and does not conflict with existing values.

Third, there is an accountable management of the mosque by trustworthy officials of the DKM Mosque, who are open and moderate. It is not a secret that if the management of a mosque is done carelessly, the results will definitely not be satisfactory. Certainly, many parties feel aggrieved and demand changes. 
Accountability is important because mosque management is not only a matter of planning and funding, but also in terms of the extent to which the mosque has received a great public trust. If the public believes it, they will come as congregation and mosque activists who are ready to help with every activity.

\section{Inhibiting Factors}

First, there is a role or influence from policy holders at the regional level to mosques that are not in accordance with the spirit of religious moderation. This is like the opposite of being involved with or involving oneself in open and moderate religious organizations.

In this case, the attitudes and views of some Bekasi City government policies that are intolerant and discriminatory towards other groups are reflected in the management of the Grand Mosque of al-Barkah Bekasi City.

Second, there are religious attitudes and views that tend to be textual from DKM administrators and mosque activists. The attitudes and views of some DKM mosque administrators appear less open and intolerant of differences, such as in terms of their attitudes and views towards minority Islamic groups.

In this case, some of the DKM mosque administrators interviewed acknowledged the importance of tolerant attitudes and views. But at the same time they still have intolerant attitudes and views and tend to be discriminatory due to certain religious insights.

Third, the lack of communication and coordination with the parties who should be the stakeholders in the mosque. In fact, this is an important requirement for the implementation of routine educational and religious activities in mosques. This is certainly not an easy thing to do, but many mosques can actually communicate and coordinate in order to meet the needs of facilities and infrastructure by holding charity activities and openly asking for help from the community.

In the Great Mosque of Al-Barkah, where the majority of funding comes from local government sources, meeting the needs for facilities and infrastructure really depends on the extent to which the administrators can approach, communicate and coordinate with the government. If the government is responsive enough, all the needs of the mosque will be fulfilled quickly.

However, if not, then a critical attitude and distrust will emerge which in turn will lead to attitudes that do not reflect the values of religious moderation. For example, if the government is considered negligent in carrying out its promises and policies to Muslims, the mosque congregation criticizes them by inviting lecturers whose content is to criticize central and regional government policies, or even to stir up the atmosphere so that controversy arises.

If things like this are allowed to continue, then gradually a mosque like this will be filled and filled with religious activities that put forward a critical, controversial attitude but far from constructive critical attitude. Communication and coordination are important for every leader and administrator of the mosque in order to cultivate the values of religious moderation among fellow administrators and also congregations of the mosque.

\section{Analysis and Discussion}

The findings of this study indicate that religious moderation has not become a common practice among the community, including mosques and their congregational bases. Religious moderation is still limited to perspectives and attitudes.

For example, in tolerance (as an indicator of religious moderation), society has had a tolerant perspective and attitude, but has not yet reached the practice. This means that they both give respect to differences and at the same time accept these differences, but in 
practice there are still double standards being found. For example, the perspective and attitude towards Shia. In general, they (mosques and congregational bases) have a moderate perspective on Shia, which is shown by giving respect to their followers, and their attitude tends to allow Shia groups to live in Indonesia.

But in practice they still claim that Shia cannot be included in the Islamic group, because there are differences in principles in them. Thus in practice they still reject Shia as part of Islam. Quoting Menchik (2016), this phenomenon is common in a community that shows the narrative of majority and minority. Sunnis are the majority in Islam in Indonesia, while Shia are the minority. In a majority-minority narrative like this, it is too naive to understand the agreement that exists between two parties as a pure agreement, which is based solely on the principle of equal rights and position, without any pressure of fear at all.

This majority-minority narrative is not just a matter of statistics, but a mindset, in which both parties have both internalized the dominant-subordinate pattern in their relationship. In the daily social interaction practice, although greeting each other occurs normally as if without any boundaries of identity, both parties have mutually realized who in the end has the right to "speak out".

In practice, persecution on behalf of the majority is one of the images that often appears. Sealing or burning of places of worship, prohibiting the implementation of traditional or religious rituals, to actions that directly threaten lives and claim victims.

Education is one of the alternatives to present the spirit of religious moderation in mosques. In other words, the mosque should be encouraged to have a role and function as a center for religious moderation education. Perspectives, attitudes and practices that are tolerant of differences must be born from the mosque.

Religious moderation education is inclusive education, not something exclusive that is separated into separate education. Heijmen (2005: 4) argues that inclusion is essentially an educational and social philosophy that values diversity, respects that all people are valuable parts of the community, regardless of differences. The inclusion philosophy views humans as equal even though they are different.

But how is the practice of these in the mosque? The diversity of congregants in the mosque is a necessity that must be respected. With an inclusive education strategy, each congregation has access and the opportunity to get this education. Whether he is a Shafi'i, Maliki, Hanafi or Hambali, they are given the right to receive education that is held in the mosque. In this way, the congregation is actually having a dialogue to get to know each other and each other, so that in the end moderate values will be born in the person.

\section{Concluding Remarks}

During the early pandemic period of 2020, especially between March - June, religious activities were almost non-existent in mosques. Then, it was done again during the New Normal period with a number of restrictions according to the health protocol.

Religious moderation education in mosques is one strategy for developing mosques to have moderate religious perspectives, attitudes and practices. It turns out that this is more comprehensive in mosques that are managed independently by the community where they have strong engagement with moderate civil society. Rather than a mosque that is funded by the local government. Why? This is because non-government mosques are more flexible in activities and funding, and have accountability responsibilities with mass organizations such as NU and Muhammadiyah. 
Meanwhile, in mosques run by the local government, they are not always more moderate. Because the nuances of religious moderation depend on the regime or the ruling leadership in the government. So, the quality of religious moderation in mosques can be said not to be determined by whether they are managed by the government or not. But it is more about how the mosques are managed by administrators affiliated with moderate civil society organizations or vice versa.

To moderate diversity in the mosque environment, local governments and offices of the ministry of religion in regencies are expected to communicate and coordinate with regards to the mosque's planning, implementing and monitoring agendas for religious and educational activities inside the mosques. Not in the context of inhibiting but coordinating so that religious and educational activities can be better organized both in terms of planning and funding.

The religious moderation program should not be enforced as a government program in mosques, but the government, through the ministry of religion in cities and districts, can urge DKM administrators and mosque leaders to study and practice indicators of religious moderation. Of course this activity must involve DKM administrators and mosque leaders with large religious organizations that are open and moderate. National and local governments are encouraged to facilitate meetings, planning and implementation of these activities in the mosques.

\begin{abstract}
About the Authors
Anik Farida is a researcher for the Center for Research and Development for Religious Life, Ministry of Religious Affairs, Indonesia. She was graduated her undergraduate program from the Faculty of Social and Politic Gadjah Mada University Yogyakarta Indonesia, and graduated her master program in the field of Gender Studies from the Indonesian University. She took doctoral program in the field of Politic at National University Jakarta Indonesia. Her research interests are gender studies, religious studies and minorities' issues. She has published her works as journal articles and books. Among of her works are "Perempuan dan Politik" ( Co-Author with Musdah Mulia, PT. Gramedia Pustaka Utama), Editor of a book "Kodrat Perempuan" (Gramedia), "Perempuan sebagai Kepala Rumah Tangga" (Gramedia), Survival Perempuan Buruh Migran" (2007), "Sikap Muhammadiyah terhadap Syiah" (Penamas Journal), "Konflik Pendirian rumah Ibadah" (Harmoni Journal), "Penyelenggaraan Haji Furodah" (Penamas Journal), "Perempuan sebagai Rekonsiliatif Konflik Sosial keagamaan" (Harmoni Journal).
\end{abstract}

Mary Silvita is researcher, writer and activist on religion and minority, gender and social issues. She has conducted research on religion, education, and government regulation on Islam on local level, and Islamic radio broadcasting in Indonesia. She has written journal articles on religious minority issues such as "Islam and Minority: A Study on Non-Muslim's Rights in Madina Charter (Refleksi Journal, UIN Jakarta, 2013); Abuse against The Religious Minority: An Obstacle for Multicultural Democracy in Indonesia (as-Sa'is Journal-Medan, 2013), Non Muslim President in The Muslim State: Manifestation of Nation State concept in The Contemporary Islamic Jurisprudence. (Islamica Jurnal- Surabaya, 2013), Islam and democracy such as Liberty and Equality in Islam and Democracy (Journal SARA-Palopo, 2014), and, among others, she has contributed a book chapter on religious radio broadcasting in Suara Salafisme: Radio Dakwah di Indonesia (Din Wahid \& Jamhari Makruf, 2017). She is Director of Center for Indonesian Cultural Initiatives, a research organization devoted for alternative voices on religion and culture and she has currently involved in the \#SaveJanda movement 
based in Jakarta as legal aid advocating the public the danger of the negative stigma against widows in Indonesia.

\section{References}

[1] Asiya, Nur, 2016. Optimalisasi Fungsi Masjid sebagai Sarana Pembinaan BKMT dan Remaja di Sitinjau Laut, Tesis, IAIN Padang.

[2] Azra, Azyumardi, CBE, 2020. Relevansi Islam Wasathiyah: dari melindungi kampus hingga mengaktualisasi kesalehan. Jakarta: Kompas.

[3] Azra, Azyumardi, CBE, 2020. Moderasi Islam di Indonesia: dari ajaran, ibadah, hingga perilaku. Jakarta: Penerbit Kencana.

[4] Dirjen Bimas Kristen Kemenag RI, 2019. Mozaik Moderasi Beragama dalam Perspektif Kristen, Jakarta: Dirjen Bimas Kristen, Kemenag RI.

[5] Kementerian Agama RI, 2019. Moderasi Beragama. Jakarta: Kemenag RI.

[6] Menchik, Jeremy, 2016. Islam and Democracy in Indonesia: Tolerance without Liberalisme, Cambridge University.

[7] Heijmen, E. 2005.Apalah Arti Sebuah Nama (Sebutan dan Istilah Berkenaan dengan Kecacatan dan Kebutuhan Pendidikan Khusus. Eenet Asia Edisi Perdana Juni.

[8] Rappler.com, 2015. "Setara Institute: Bogor Bekasi Kota Paling Intoleran di Indonesia. Jakarta: November 16. Diakses 21 [9] Agustus 2020, jam 11:14 WIB. Website: https://rappler.com/world/ setarainstitute-bogor-bekasi-kota-intoleran-indonesia

[9] Setara Institute, 2015. Bogor the Most Intolerant City in Indonesia. Diakses 15 Agustus 2020 jam

16:11 WIB, Website : http://setara-institute.org/en/english-bogor-the-most-intolerant-city-in-indonesia/

[10] Republika, 2018. "Penjelasan Survey P3M: Masjid Disusupi Radikalisme," Jakarta: 19 November. Diakses 19 Agustus 2020, jam 10:22 WIB. Website: https://republika.co.id/berita/pifsg1409/penjelasansurvei-p3m-masjid-disusupi-radikalisme

[11] Sidi Gazalba, 1994. Masjid: Pusat Ibadat dan Kebudayaan Islam. Jakarta: Pustaka Al Husna.

[12] The Wahid Institute, 2011. Lampu Merah Kebebasan Beragama di Indonesia, Jakarta: The Wahid Institute.

[13] The Wahid Institute, 2015. Laporan Tahunan Kebebasan Beragama/Berkeyakinan dan Intoleransi. Jakarta: The Wahid Institute. 